\title{
A comparative review between the updated models of Brazilian, United Kingdom and American eye banks and lamellar transplants
}

\author{
Uma revisão comparativa entre os modelos atuais \\ de bancos de olhos e transplantes lamelares do Brasil, \\ Reino Unido e Estados Unidos
}

Gustavo Victor ${ }^{1}$, Sidney Júlio de Faria e Sousa², Marcos Alonso Garcia ${ }^{1}$, Mário Henrique Camargos de Lima ${ }^{1}$, Milton Ruiz Alves

\begin{abstract}
The corneal transplantation (CT) is the most commonly performed type of transplant in the world and the Eye Banks are organizations whose capture, evaluate, preserve, store and distribute ocular tissues. With the evolution of surgical techniques and equipment for $\mathrm{CT}$, the BOs had to evolve to keep up with these requirements. This evolution goes from tissues capture techniques, donating money and clarification to the patient (e.g. internet-based), use of current equipment for more adequate tissues supply for the most current surgical techniques, integration of BOs of certain country and real-time management of stocks of ocular tissues, and adequacy of laws that manage the entire process. This review aims to make a comparative review between the updated models of Brazilian, United Kingdon and American Eye Banks. Like, check what the trend towards lamellar transplants in these three countries.
\end{abstract}

Keywords: Cornea; Corneal transplantation; Laser; Health services administration; Benchmarking; Brazil; United States

\section{RESUMO}

O transplante de córnea (CT) é o tipo de transplante mais realizado no mundo e os Bancos de Olhos (BO) são organizações que capturam, evoluem, preservam, guardam e distribuem tecidos oculares. Com a evolução das técnicas cirúrgicas e equipamentos para o CT, os BOs precisaram evoluir para acompanhar estas necessidades. Esta evolução vai desde técnicas de captura de tecidos; doação de dinheiro e esclarecimento ao paciente (baseadas na internet, por exemplo); utilização de equipamentos modernos, para fornecimento mais adequado de tecidos para técnicas cirúrgicas mais atualizadas; integração dos BOs de determinado país e gerenciamento em tempo real dos estoques de tecidos oculares, e adequação das leis que gerem todo este processo. Esta revisão tem como objetivo fazer uma comparação dos modelos atualizados de BOs brasileiro, inglês e americano, além de avaliar a tendência dos tipos de CT nestes países e sugerir melhorias ao modelo de BO brasileiro.

Descritores: Córnea; Transplante de córnea; Laser; Administração de serviços de saúde; Benchmarking; Brasil; Estados Unidos

'Faculdade de Medicina da Universidade de São Paulo (SP), Brazil;

${ }^{2}$ Faculdade de Medicina de Ribeirão Preto da Universidade de São Paulo - Ribeirão Preto (SP), Brazil.

The authors declare no conflicts of interest. 


\section{INTRODUCTION}

\section{Eye Banks}

The Eye Banks are nonprofit organizations whose capture, evaluate, preserve, store and distribute ocular tissues. Anywhere in the world through local legislation, these organizations were created, are regulated and inspected.

\section{Lamellar Transplants}

The lamellar transplantation (LT) was first performed by Von Hippel in $1888^{(1)}$. This technique is more difficult to do and used to provide less visual acuity than the penetrant keratoplasty (PK). For these reasons, especially, the LT until about a decade ago, was done mostly for tectonic and/or cosmetics purposes, and the PK used for optical purposes, where wanted best final visual acuity, even if the patient needed to replace only part of the cornea, anterior or posterior ${ }^{(2)}$. With the development of Eye Banks, surgical techniques and equipment as the artificial anterior chamber, microkeratome and femtosecond lasers, LT was more refined and technically reproducible, thus getting significant improvement in final visual acuity ${ }^{(2-10)}$. Thus, LT (anterior or posterior) is becoming the technique of choice in conditions in which it is only necessary to exchange a part of the cornea (anterior or posterior) ${ }^{(2,3,9,10)}$, as keratoconus and endothelial dysfunction. These two diseases remain among the top three causes of transplants in world ${ }^{(9,10)}$.

This review aims to make a comparative review between the updated models of Brazilian, United Kingdon and American Eye Banks. Like, check what the trend towards lamellar transplants in these three countries.

\section{In Brazil}

Transplants

Brazil ranks second in the absolute number of transplants performed annually worldwide. If we consider the relative number of transplants and GDP (gross national product), Brazil ranks third, favored by investments made in this area and the stimulus given to its increase ${ }^{(11)}$. Table 1 shows the evolution of the types of transplants in Brazil between 2001 and 2011.
The importance of corneal transplantation (CT) for Brazil can be observed, both by popular demand as the state investment, as represented $63.42 \%$ of all transplants performed in Brazil in 2011. In 2009, the MS invested about $\mathrm{R} \$ 900$ million in transplants ${ }^{(12)}$. Despite the increase in the number of corneal transplants in Brazil, can be seen in Table 2 the great difference in numbers of transplants in several Brazilian States over the years, which reflects the inefficiency in generating a model of Eye Banks efficient nationwide.

Can be observed that there are states that do not perform any CT in 2011, another did not perform CT between 2001-2009, and that there are more developed states having fewer transplants than other less developed. On the other hand, only the State of São Paulo was responsible for $37.39 \%$ of corneal transplants performed in Brazil in 2011.

\section{Lamellar Transplants}

Of these nearly 15,000 CT held in Brazil in 2011, do not know for sure how many were LT and how many were PK, because there isn't this kind of statistical control in Brazil.

\section{In United Kingdon}

Like in Brazil, if no wish has been expressed in life then specially trained healthcare professionals should approach the family for their authorization to proceed, based on their knowledge of the potential donor (opt-in) ${ }^{(13)}$. Currently there are 14 European nations operating under a system of opt-out or 'presumed consent': Austria, Belgium, Czech Republic, Finland, France, Greece, Hungary, Italy, Luxembourg, Poland, Portugal, Slovak Republic, Spain, Sweden ${ }^{(13)}$. In UK, 16.124.871 people (The total at 31 March 2009) registered on the NHS Organ Donor Register $^{(13)}$ (a web based database).

\section{Transplants}

Figure 1 shows the evolution of the number of corneas donated and the number of corneas grafted in the UK between 2002 and $2012^{(14)}$.

Figure 2 shows the evolution, in a decade, of the numbers of LT for keratoconus, preserving the patient's healthy endothelium and changing only the corneal stroma ${ }^{(9)}$.

Table 1

Evolution of the types of transplants in Brazil between 2001 and 2011

\begin{tabular}{|c|c|c|c|c|c|c|c|c|c|c|}
\hline \multirow[t]{2}{*}{ Ano } & \multicolumn{7}{|c|}{ Órgãos sólidos } & \multirow{2}{*}{$\begin{array}{c}\text { Tecido ocular } \\
\text { Córnea }\end{array}$} & \multirow{2}{*}{$\begin{array}{c}\text { Células } \\
\text { TMO }\end{array}$} & \multirow[t]{2}{*}{ Total } \\
\hline & Coração & Fígado & Pulmão & Rim & Pâncreas & Rim/Pâncreas & Fígado/Rim & & & \\
\hline 2001 & 143 & 542 & 25 & 2672 & 39 & 105 & 6 & 6.193 & 703 & 10.428 \\
\hline 2002 & 149 & 654 & 36 & 2.714 & 57 & 161 & 5 & 6.556 & 871 & 11.203 \\
\hline 2003 & 181 & 794 & 43 & 2.911 & 53 & 203 & 9 & 7.556 & 972 & 12.722 \\
\hline 2004 & 200 & 914 & 39 & 3.126 & 94 & 201 & 10 & 8.394 & 1.197 & 14.175 \\
\hline 2005 & 181 & 939 & 42 & 2.903 & 112 & 108 & 8 & 9.970 & 1.307 & 15.570 \\
\hline 2006 & 155 & 978 & 55 & 2.961 & 88 & 125 & 12 & 10.382 & 1.032 & 15.788 \\
\hline 2007 & 159 & 971 & 50 & 3.040 & 78 & 116 & 33 & 11.419 & 1.439 & 17.305 \\
\hline 2008 & 205 & 1.110 & 53 & 3.154 & 43 & 127 & 26 & 12.825 & 1.446 & 18.989 \\
\hline 2009 & 201 & 1.322 & 59 & 4.259 & 39 & 119 & & 12.723 & 1.531 & 20.253 \\
\hline 2010 & 167 & 1.404 & 60 & 4.660 & 44 & 87 & & 12.923 & 1.695 & 21.040 \\
\hline 2011 & 159 & 1.496 & 49 & 4.939 & 54 & 130 & & 14.838 & 1.732 & 23.397 \\
\hline
\end{tabular}

Source: http://aplicacao.saude.gov.br/portal/public/transplantes/destaque/dest5. Accessed on 04/21/2012 
Table 2

Annual change in the number of corneal transplants by Brazilian State (2001-2011)

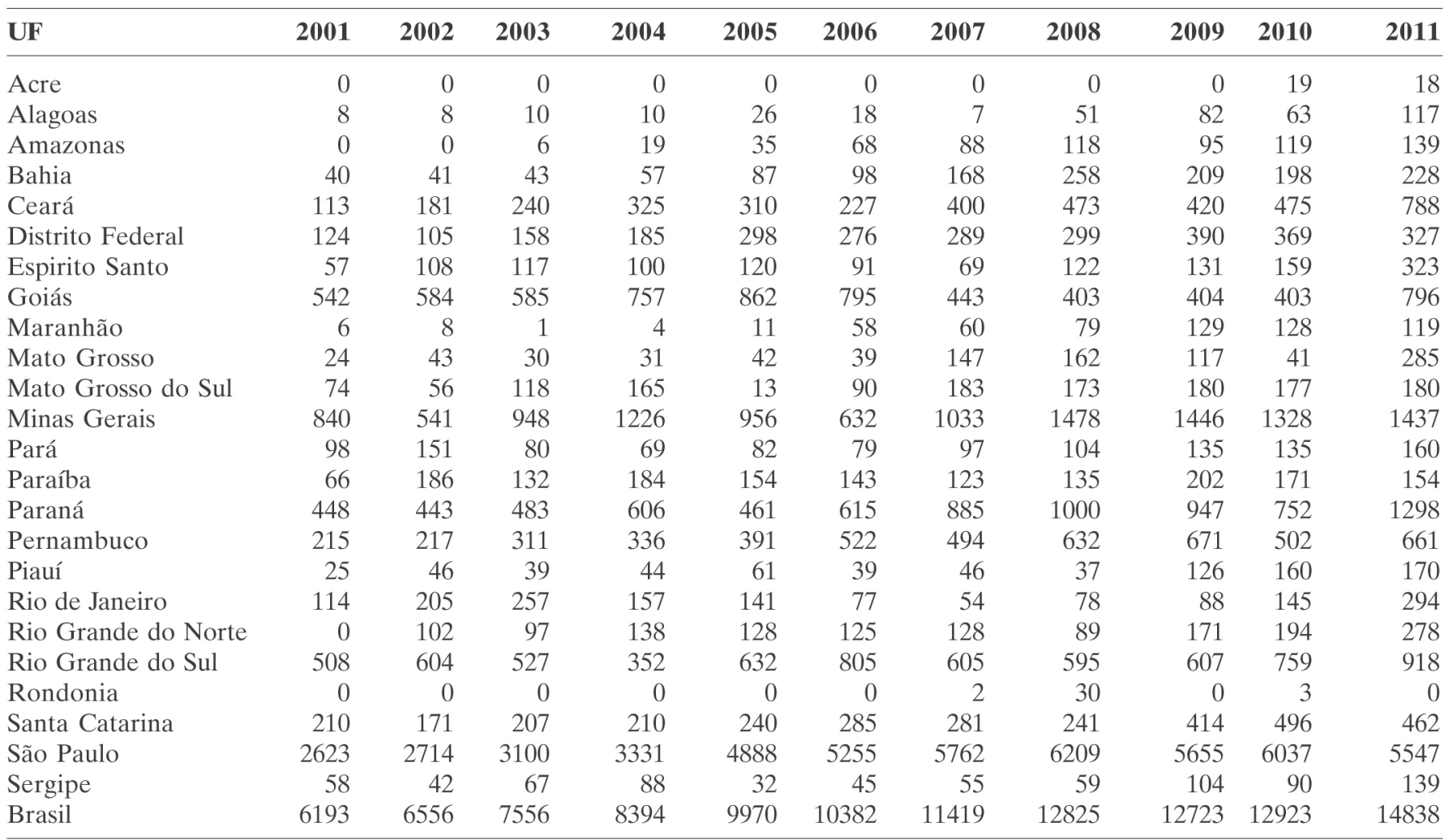

Source: http://aplicacao.saude.gov.br/portal/public/transplantes/destaque/dest5; accessed on 04/21/2012

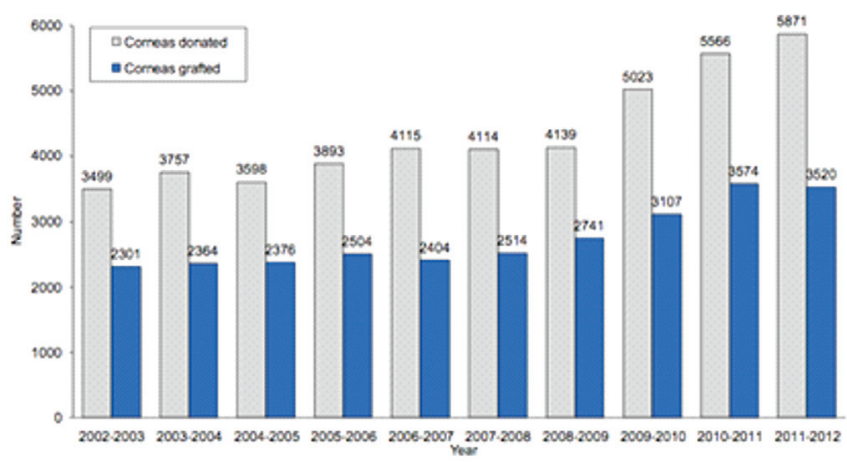

Source:http://www.organdonation.nhs.uk/statistics/ transplant_activity_report/archive_activity_reports/

Figure 1: Evolution of the number of corneas donated and the number of corneas grafted in the UK between 2002 and 2012 $2^{(14)}$

Figure 3 shows the evolution, in a decade, of the numbers of LT for endothelial failure, preserving the patient's healthy stroma and changing only the corneal endothelium ${ }^{(9)}$.

In the UK it is possible to request and receive from Eye Bank a corneal donor lamella with specific thickness and diameter to the realization of LT. As in Brazil, the patient dosen't pay to the donnor cornea.

\section{In United States}

Currently, there are 84 Eye Banks in the U.S. In 2013, the Eye Bank Association of America (EBAA) published the statistical

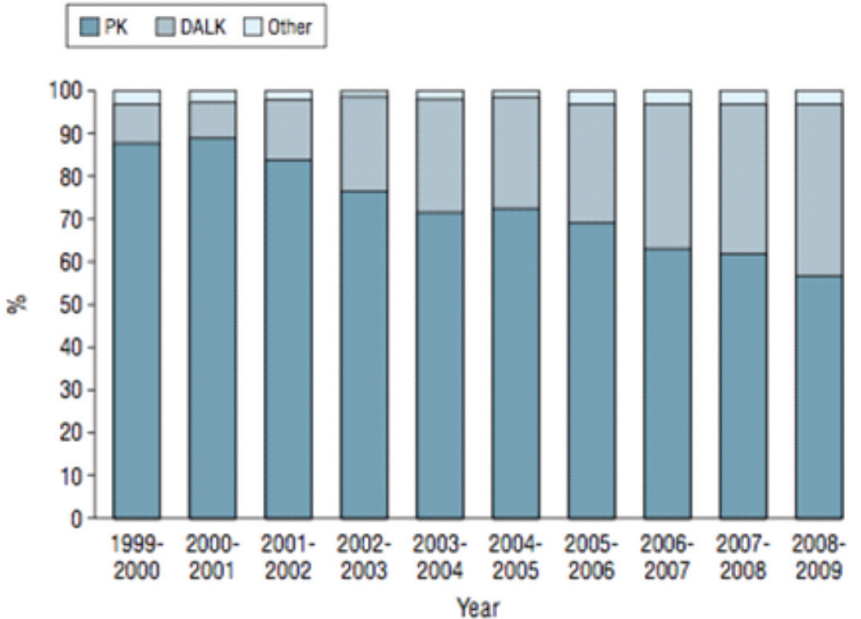

Source: Trends in the Indications for Corneal Graft Surgery in the United Kingdom: 1999 Through 2009. Arch Ophthalmol. 2012;130(5):621-628

Figure 2: Evolution, in a decade, of the numbers of LT for keratoconus. PK: Penetrant keratoplasty, DALK: Deep anterior lamellar keratoplasty ${ }^{(9)}$

report for $2012^{(10)}$. Since 2011, the EBAA began a new monthly collection methodology for the Statistical Report using EBAA CONNECT, a real-time, web-based statistical reporting and analytics engine designed specifically for the EBAA by Transplant 


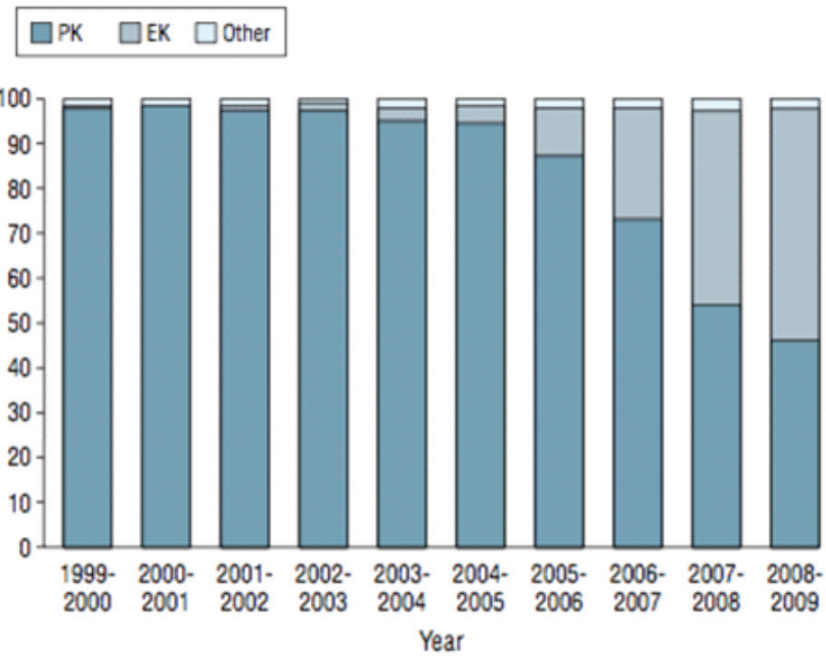

Source: Trends in the Indications for Corneal Graft Surgery in the United Kingdom: 1999 Through 2009. Arch Ophthalmol. 2012;130(5):621-628

Figure 3: Evolution, in a decade, of the numbers of LT for endothelial failure, preserving the patient's healthy stroma and changing only the corneal endothelium ${ }^{(9)}$; PK: Penetrant keratoplasty; EK: Endothelium keratoplasty

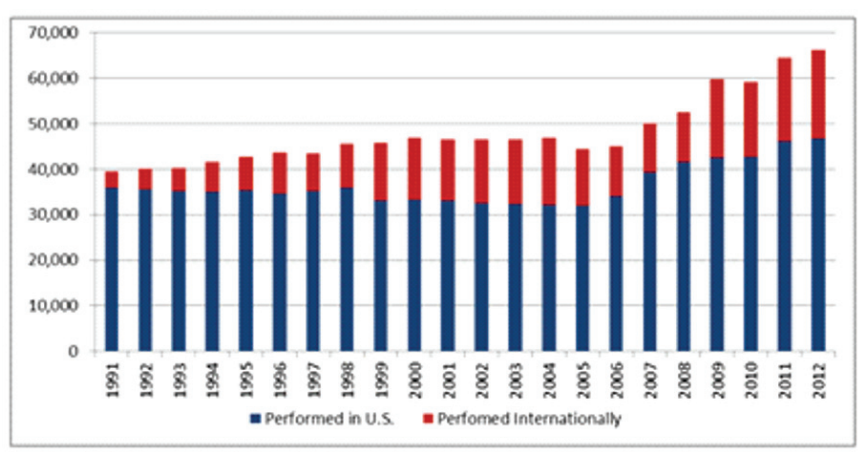

Source: Eye Bank Association of America. 2012 Banking Statistical Report

Figure 4: Shows the annual number of corneal transplants supplied by U.S. Eye Banks (US and exported) ${ }^{(10)}$

Connect $^{\Theta(10)}$. In this study, the data reported were from 80 Eye Banks. Prior to 2008, all keratoplasties were counted as "penetrating keratoplasty". From 2008, pre-cut and uncut tissue utilization was stratified into penetrating grafts (PK), endothelial keratoplasty (EK), anterior lamellar keratoplasty (ALK), keratolimbal allografts (KLA), and tectonic grafts (TK). Keratoprosthesis (K-Pro) as a specific utilization was added in 2009. Before 2009, domestic and international data from U.S eye banks were combined. In 2009 and 2010, stratified data was only collected for tissue distributed and used within the U.S. For 2011 and beyond, tissue provided by U.S. eye banks was stratified and separated into domestic and international use. International use of tissue sent from U.S. eye banks was generally not included in statistical analysis before $201^{(10)}$.

\begin{tabular}{lcc}
\hline Year & Total provided by U.S. & Performed in U.S. \\
\hline 1991 & 39,515 & 35,831 \\
1992 & 39,973 & 35,525 \\
1993 & 40,215 & 35,173 \\
1994 & 41,539 & 35,022 \\
1995 & 42,740 & 35,300 \\
1996 & 43,711 & 34,668 \\
1997 & 43,492 & 35,209 \\
1998 & 45,579 & 35,861 \\
1999 & 45,765 & 33,020 \\
2000 & 46,949 & 33,260 \\
2001 & 46,532 & 33,035 \\
2002 & 46,440 & 32,559 \\
2003 & 46,436 & 32,240 \\
2004 & 46,841 & 32,106 \\
2005 & 44,329 & 31,952 \\
2006 & 45,035 & 33,962 \\
2007 & 50,122 & 39,391 \\
2008 & 52,487 & 41,652 \\
2009 & 59,784 & 42,606 \\
2010 & 59,271 & 42,642 \\
2011 & $67,590^{3}$ & 46,196 \\
2012 & $68,681^{2}$ & 46,684 \\
\hline
\end{tabular}

Source: Eye Bank Association of America. 2012 Banking statistical report

Figure 5: Number of corneas available and how these have been used for transplants in the USA between 1991-2012; in 2011 and progressing, long-term preserved corneal tissue is included in the total ${ }^{(10)} \cdot{ }^{(3)}$ Until 2010 , corneal grafts total did not include long-term preserved corneal tissue

Beginning in 2012, eight international banks began using the EBAA Connect data system ${ }^{(10)}$.

\section{Transplants}

In the U.S., tissue supplied by U.S. Eye Banks for all keratoplasty procedures types in 2012 was 68,681. Of these tissues, 46.684 were used to transplants in US and 19,546 corneas were exported internationally ${ }^{(10)}$. The Figure 4 shows the annual number of corneal transplants supplied by U.S. Eye Banks (US and exported $)^{(10)}$.

Figure 5 shows annually, the number of corneas available and how these have been used for transplants in the USA between $1991-2012^{(10)}$.

\section{Lamellar Transplants}

Figure 6 shows the annual number of surgeries by type of cornea transplant between 2005-2012 ${ }^{(10)}$.

It can be seen that since 2011 the number of LT (anterior and posterior) is greater than the number of PK, and that in 2012 the number of posterior LT alone was greater than the number of PK.

In the United States all Eye Banks provide donor corneal lamellae. The current cost of a corneal donor (lamella or not) varies on average between US\$ $1,949.00$ to US\$2,449.00 ${ }^{(15)}$.

\section{Comments and suggestions}

Although the penetrating keratoplasty indications were similar in the world ${ }^{(9,10,16-20)}$, management of eye banks model have improved in Brazil ${ }^{(21)}$ and the Brazilian corneal surgeons perform the most updated techniques of CT, it can be seen 


\begin{tabular}{|c|c|c|c|c|c|c|c|c|}
\hline Domestic surgery use & 2012 & 2011 & 2010 & 2009 & 2008 & 2007 & 2006 & 2005 \\
\hline Endothelial Keratoplasty & 23,049 & 21,555 & 19,159 & 18,221 & 17,468 & 14,159 & 6,027 & 1,398 \\
\hline Keratolimbal Allograft & 80 & 69 & 130 & 120 & 173 & 207 & 138 & 175 \\
\hline
\end{tabular}

Figure 6: The annual number of surgeries by type of cornea transplant between 2005-2012(10).

that there is an inefficiency of the Brazilian system at the national level by the huge discrepancy in the number of transplants in several Brazilian states. In 2010, only São Paulo made 1.7 times more CT than all UK did in 2012. In 2011, Brazil made 4.2 times more CT than all UK did in 2012. In the other hand, in 2011, the EUA performed 3.11 times more CT than Brazil in the same year. In this same period, the US exported more corneas than the number of CT across Brazil. Thus it is important to consider whether the Brazilians Eye Bank are following trends and best practices of other major Eye Banks in the First World. The three countries use the optin system for cornea donation.

Clearly, it is observed that in the United States (since 2011) and the UK (since 2009) are performed more posterior LT (endothelial) than PK. There is also a significant number of anterior LT in these countries. In this issue specifically, in Brazil the vast majority of Eye Banks as corneal surgeons do not have equipment (microkeratome, artificial anterior chambers, femtosecond lasers) for manufacturing their own donor corneal lamellar (anterior or posterior) from the donor corneal-scleral button. Thus, the number of LT performed in Brazil is a tiny fraction of the total CT. So, despite being a global trend, the LT is not encouraged by the Brazilian Eye Bank System, where there is practically no supply of donor corneal lamellae by Eye Banks, as in England or the United States have.

\section{Suggestions}

1. Investment in national awareness campaigns, guidance and fundraising (donations, web-donations with CBO help);

2. Specific guidance program to improve patient's knowledge about the main causes of CT and its treatments ${ }^{(22)}$;

3. Developing a specific guidance program on protocols related to the importance, capture and donation of organs and tissues for TC, intended for all physicians and key stakeholders such as: CNCDOs, Intra-Hospital commissions, State and Municipal Health;

4. Investment for the 24 hours system of communication, transportation and collection nationwide;

5. Allow Eye Banks operate outside hospitals;

6. Partnership between the MS and the Brazilian Council of Ophthalmology (CBO) to develop and implement, in all national Eye Banks, software for on-line management, supervision and control of donated tissues and all types of cornea transplants;

7. Investment in equipment, material and human resources in Eye Banks for the possibility of making donor corneal lamellae;

8. Possibility to enrollment lamellar transplant (anterior and posterior) on Eye Banks;

9. Creating a web based database for the population could enroll as organ donors and tissues, as well as be able to make financial donations.

\section{REFERÊNCIAS}

1. von Hippel A. Eine neue Methode der Hornhauttransplantation. Albrecht Von Graefes Arch Ophthalmol. 1888;34(1):108-30.

2. Reinhart WJ, Musch DC, Jacobs DS, Lee WB, Kaufman SC, Shtein RM. Deep anterior lamellar keratoplasty as an alternative to penetrating keratoplasty a report by the american academy of ophthalmology. Ophthalmology. 2011;118(1):209-18.

3. Lee WB, Jacobs DS, Musch DC, Kaufman SC, Reinhart WJ, Shtein RM. Descemet's stripping endothelial keratoplasty: safety and outcomes: a report by the American Academy of Ophthalmology. Ophthalmology. 2009;116(9):1818-30. Review.

4. Baptista GV. Método de avaliação da qualidade de corte na confecção de lamela corneana pediculada por microcerátomo em laser in situ ceratomileusis [tese]. Ribeirão Preto: Universidade de São Paulo; 2005.

5. Behrens A, Dolorico AM, Kara DT, Novick LH, McDonnell PJ, Chao LC, et al. Precision and accuracy of an artificial anterior chamber system in obtaining corneal lenticules for lamellar keratoplasty. J Cataract Refract Surg. 2001;27(10):1679-87.

6. Springs CL, Joseph MA, Odom JV, Wiley LA. Predictability of donor lamellar graft diameter and thickness in an artificial anterior chamber system. Cornea. 2002;21(7):696-9.

7. Victor G, Faria e Sousa SJ,Alves MR, Nosé W. [MALKS: specifications and development]. Arq Bras Oftalmol. 2006;69(2):151-5. Portuguese.

8. Victor G, Sousa SJ,Alves MR, Nosé W. Evaluation of a new system for obtaining donor lamellar grafts. Cornea. 2007;26(2):151-3.

9. Keenan TD, Jones MN, Rushton S, Carley FM; National Health Service Blood and Transplant Ocular Tissue Advisory Group and Contributing Ophthalmologists (Ocular Tissue Advisory Group Audit Study 8). Trends in the indications for corneal graft surgery in the United Kingdom: 1999 through 2009. Arch Ophthalmol. 2012;130(5):621-8.

10. Eye Bank Association of America. 2012 Banking statiscal report [Internet]. Washington,DC: Eye Bank Association of America; 2013 [cited $2013 \mathrm{Feb}$ 10].Available from:http:/www.restoresight.org/wp-content/uploads/2013/ 04/2012_Statistical_Report_FINAL-reduced-size-4-10.pdf

11. Sistema Nacional de Transplantes. [citado 2012 Abr 21]. Disponível em: http://www.cbo.com.br/novo/medico/pdf/02-cegueira.pdf

12. Flaeschen D. Transplantes. Doa-se vida: Brasil dispara em transplantes de órgãos e cresce também em número de doadores. IPEA [periódico na internet]. 2010. [citado 2012 Abr 21];63 [cerca de 5p.]. Disponível em: http://www.ipea.gov.br/desafios/ index.php?option=com_content $\&$ view=article $\& i d=1297$ :reportagensmaterias $\&$ Itemid $=39$

13. Organ donation. Organ donation: teaching resource pack [internet]. Edinburgh: Scottish executive; 2003 [cited 2013 Feb 10]. Available from: http://www.scotland.gov.uk/Publications/2003/ $11 / 18095 / 25886$

14. UK Activity Report 2001-2012 [Internet]. [cited 2014 Mar 16]. Available from: http://www.organdonation.nhs.uk/statistics/ transplant_activity_report/archive_activity_reports/ 
15. Eye Bank Association of America. Cost-benefit analysis of corneal transplant [internet]. Washington, DC: Eye Bank Association of America; 2013 [cited 2013 Feb 10]. Available from: http://www.restoresight.org/ wp-content/uploads/2013/09/Lewin-Study-2013.pdf

16. Victor G, Barth B, Signorelli Junior A. [Evaluate penetrating keratoplasty indications]. Rev Bras Oftalmol. 2002;61(3):174-8. Portuguese.

17. Ghosheh FR, Cremona F, Ayres BD, Hammersmith KM, Cohen EJ, Raber IM, et al. Indications for penetrating keratoplasty and associated procedures, 2001-2005. Eye Contact Lens. 2008;34(4):211-4.

18. Zhang $\mathrm{C}, \mathrm{Xu}$ J. Indications for penetrating keratoplasty in East China, 1994-2003. Graefes Arch Clin Exp Ophthalmol. 2005;243(10):1005-9.
21. Hilgert CV, Sato ÉH. [Management performance of eye banks and its impact on those organizations results]. Rev Bras Oftalmol. 2012;71(1):28-35. Portuguese.

22. Kara-Junior N, Mourad PC, Espíndola RA, AbilRuss HH. [Expectation and knowledge among patients with keratoplasty indication]. Rev Bras Oftalmol. 2011;70(4):230-4. Portuguese.

\section{Corresponding author:}

Gustavo Victor

Republica do Líbano Avenue, $\mathrm{n}^{\circ} 1034$

Zip code: 04002-001 - São Paulo (SP), Brazil

Phone: +55 (11) 3884-2020 - Fax: +55 (11) 3884-7680

E-mail: gustavo.victor@eyeclinic.com.br 